\title{
A Brief Biography of Tang Yijie, the Honorary Member of the Society
}

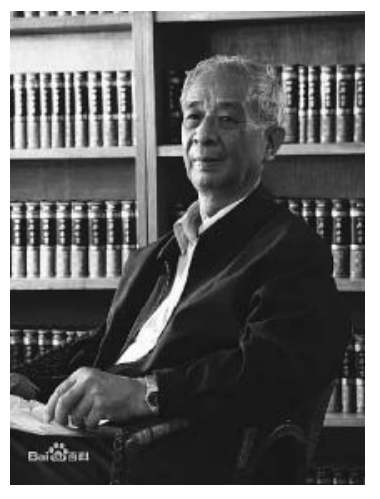

Professor Tang Yijie 汤一介 (1927-2014) was a well-known philosopher, historian of philosophy, and teacher of philosophy. He was also a endowed professor of philosophy at Peking University and an important area expert and editor-in-chief for the Rucang 儒藏 (Confucian Corpus) project. In addition, he was honorary director of the Confucianism Research Institute, founding president of the Academy of Chinese Culture, president of the Chinese Confucian Academy, vice president of the Association for Yan Huang Culture of China, vice chairman of the International Federation of Daoism, and member of the Central Research Institute of Culture and History. He held honorary doctoral degrees from McMaster University in Canada and Kansai University in Japan. Among his accolades, he counted the Peking University Philosophy Department Lifetime Achievement Award in Philosophy Instruction, the Confucian Culture Award, and the Wu Yuzhang Lifetime Achievement Award in the Humanities and Social Sciences.

Tang Yijie was born on February 16, 1927 in Tianjin. His ancestral home was Huangmei in Hubei Provence. In 1947 he began his studies in the Philosophy Department of Peking University, and in 1951 he began working at the Beijing Administrative College. In 1956 he was transferred back to the Philosophy Department of Peking University, where he became associate professor in 1981, professor and doctoral student advisor in 1985, and endowed professor in 2006.

Professor Tang's primary areas of specialization in instruction and research were Neo-Daoism of the Wei and Jin periods; early Daoism, Buddhism, Confucianism, and East-West cultural relations; and Marxist philosophy. His major works include Guo Xiang yu Wei Jin xuanxue (Guo Xiang and Neo-Daoism of the Wei and Jin Periods, 1983), Zaoqi daojiao shi (A History of Early Daoism, 2006), Zhongguo chuantong wenhua zhong de Ru, Dao, Shi (Confucianism, Daoism, and Buddhism in Traditional Chinese Culture, 1988), Ru, Dao, Shi yu neizai chaoyue wenti (Confucianism, Daoism, and Buddhism and the Problem of the Inherent Transcendental, 1991), Confucianism, Buddhism, Daoism, Christianity, and Chinese Culture (1991), Zai feiyou feiwu zhi jian (Between Existence and Nonexistence, 1995), Feishi feixu ji (A Collection of Essays on the Nonreal and Nonempty, 1999), Xi bu zhi jin (The 
Past Does Not Extend to the Present, 1999), Fojiao yu Zhongguo wenhua (Buddhism and Chinese Culture, 1999), He er bu tong (Harmonious Yet Different, 2001), Wo de zhexue zhi lu (My Path in Philosophy, 2006), Ruxue shi lun ji wai wu pian (Ten Commentaries on Confucianism, 2009), and Zhuwang xin zhouxin shidai (Hopes for a Newly Centered Age, 2014). ${ }^{1}$ All of these works can be found in the ten-volume collection Tang Yijie ji (Works of Tang Yijie, 2014). ${ }^{2}$

In the 1980s Professor Tang established the Academy of Chinese Culture, which at the time led to great interest in culture. In 2003, when he was in his seventies, he initiated and managed the Confucian corpus project Rucang, which at present has nearly fifty academic institutions (in China, South Korea, Japan, and Vietnam) and over four hundred scholars participating. The compilation of Rucang attracted wide notice in society for establishing a firm foundation for researching and promoting traditional culture. In 2011 Professor Tang, as editor in chief, finished compiling the nine-volume Zhongguo Ruxue shi (The History of Chinese Confucianism). ${ }^{3}$ This general history of Chinese Confucianism is the most extensively sourced, the richest in content, and the most systematic history of Confucianism to the present. It received the Twelfth Beijing Special Award for an Outstanding Work in Philosophy and the Social Sciences, the General Administration of Newspaper Publications Fourth Outstanding Publication Award, and the Third Government Chinese Publication Award.

Professor Tang was a pioneer in the field of Chinese philosophy and thought. In his understanding of the spirit of Chinese philosophy, research in the Neo-Daoism of the Wei and Jin periods, explorations into Daoism and

1 Guo Xiang yu Wei Jin xuanxue 郭象与魏晋玄学 (Wuhan: Hubei Renmin Chubanshe, 1983), Zaoqi daojiao shi 早期道教史 (Beijing: Kunlun Chubanshe, 2006), Zhongguo chuantong wenhua zhong de Ru, Dao, Shi 中国传统文化中的儒道释 (Beijing: Zhongguo Heping Chubanshe, 1988). Ru, Dao, Shi yu neizai chaoyue wenti 儒道释 与内在超越问题 (Nanchang: Jiangxi Renmin Chubanshe, 1991), Confucianism, Buddhism, Daoism, Christianity, and Chinese Culture (Washington, D.C.: Council for Research in Values and Philosophy, 1991), Zai feiyou feiwu zhi jian 在非有非無 之間 (Taipei: Zhengzhong Shuju, 1995), Feishi feixu ji 非实非虚集 (Beijing: Huawen Chubanshe, 1999), Xi bu zhi jin 昔不至今 (Shanghai: Shanghai Wenyi Chubanshe, 1999), Fojiao yu Zhongguo wenhua 佛教与中国文化 (Beijing: Zongjiao Wenhua Chubanshe, 1999), He er bu tong 和而不同 (Shenyang: Liaoning Renmin Chubanshe, 2001), Wo de zhexue zhi lu 我的哲学之路 (Beijing: Xinhua Chubanshe, 2006), Ruxue shi lun ji wai wu pian 儒学十论及外五篇 (Beijing: Beijing Daxue Chubanshe, 2009), and Zhuwang xin zhouxin shidai 瞩望新轴心时代 (Beijing: Zhongyang Bianyi Chubanshe, 2014).

2 Tang Yijie ji 汤一介集 (Beijing: Zhongguo Renmin Daxue Chubanshe, 2014).

3 Tang Yijie 汤一介, Li Zhonghua 李中华, eds., Zhongguo ru xue shi 中國儒學史, 9 vols. (Beijing: Beijing Daxue Chubanshe, 2010-2011). 
Buddhism, ability to discover new ways of explaining Chinese culture, ability to conceptualize past and present cultural issues, and ability to plan and direct great scholarly projects, he displayed a brilliant scholarly awareness that seemed divinely inspired and an intellectual spirit that united people in a common enterprise. Professor Tang devoted his life to the great enterprise of reconstructing Chinese culture for the new age.

May he forever rest in peace!

http://www.phil.pku.edu.cn/tyj/tangyijie.html
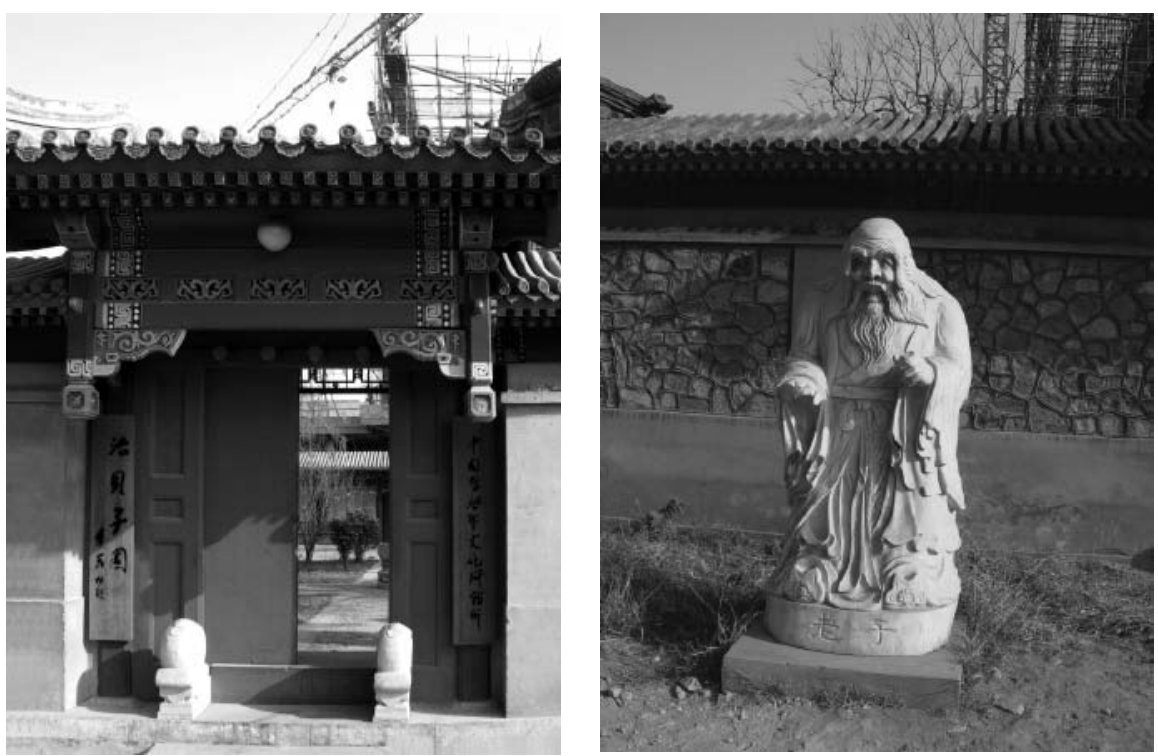

Zhongguo wenhua shuyuan (Academy for Chinese Culture) in Peking University was co-founded by Professor Tang in 1984.

Photos by De-min Tao 